\title{
8. A will in search of a way: philanthropy in education in Peru
}

Matthew D. Bird and Vicente M. León

The ingredients for strong and strategic institutionalised philanthropy exist in Latin America: charitable traditions, rapid wealth creation from the global commodity boom and weaker than expected state social services (Hauser Center, 2016; Johnson, 2018; Sanborn \& Portocarrero, 2005). Peru is an exemplary regional case (León \& Bird, 2018; Portocarrero, Sanborn, Cueva \& Millán, 2002). Due mostly to increased mining exports in the early 2000s, the World Bank reclassified Peru as an upper middleincome country, which prompted overseas development assistance (ODA) organisations, comprised of multilateral and private institutions, to shift resources outside the country and call on local entities to better channel wealth to address social issues. Local philanthropists sought to meet the challenge, with over half of the country's philanthropic organisations founded after 2000 .

Still, Peru's human capital remains that of a lower middle-income economy and its educational achievements rank low in international evaluations (Organisation for Economic Co-operation and Development [OECD], 2016). This lack of human capital spurred the creation of new local education-focused philanthropies, which account for the majority of the country's philanthropic organisations and a third of the philanthropic capital, according to a national survey (León \& Bird, 2018). The will exists for change in Peru's education sector, yet clear pathways for how to scale these initiatives have yet to appear.

What new philanthropic and social investment models are emerging and what lessons does Peru offer to other countries caught in what we consider the middle-income social investment trap?

We base our responses on an original qualitative and quantitative survey of 157 philanthropic and social investment organisations in Peru's 10 largest cities. First, we frame the role of philanthropy in education in Peru in the context of the development of philanthropy in the education sector and its relationship with the state. We then explain how Peru's strong economic performance since the year 2000 led to its reclassification as an upper 
middle-income country and the challenge this posed as international aid dwindled. We show how Peru's middle-income status did not translate into an improvement in quality of life indices, particularly education, as Peru's weak performance in international student assessments demonstrate. After detailing our methodology, we map the philanthropic organisations working in education in Peru and discuss characteristics such as the size of their investments, age, revenue models, beneficiaries and geographic scope. We then analyse how the organisations' transparency, governance and operational mechanisms reflect institutional quality in the sector, before concluding with questions about how the aforementioned components of institutional quality may provide a prescription for pathways to scale with impact not only in Peru but in other middle-income countries.

\section{PHILANTHROPY, EDUCATION AND THE STATE}

Philanthropic investment in education has been present since the birth of modern philanthropy in the United States, where in the late 1800s the education sector attracted private capital from the globe's first modern philanthropic institutions. In some respects, the U.S. case offers lessons for understanding the role philanthropy plays in education in emerging markets, especially among middle-income countries.

Philanthropy has played an active role in U.S. education for over a century. Beginning in the early 1980s and coinciding with a shift in the relationship between the government and private sector, policyoriented education philanthropy reemerged with a focus on reform. The United States has passed through two waves of reform movements (Soskis \& Katz, 2016). The first lasted until the end of the twentieth century, while the new reform-represented by the Ford, Kellogg, Gates and Broad Foundations - sought to inject greater accountability and market-oriented principles into their efforts (Tompkins-Stange, 2016). In contrast, the building of European education systems benefited from the development of a welfare state which may have crowded out philanthropic activities. Likewise, in parts of Asia, strong centralised states in former middle-income countries such as Hong Kong, Singapore, South Korea and Taiwan, assumed responsibility for designing, investing in and implementing robust education policies. Scholars cite increased education quality as a critical factor for their success (Stiglitz, 1996).

In Latin America, the relative weakness of state capacity and the creation of pockets of private wealth make the region more comparable to the United States with its decentralised education system and philanthropic culture than to European or Asian countries that benefited from more 
centralised state systems. However, this comparison only goes so far since many Latin American countries are caught in a middle-income trap. The region faces two main pathways for escaping the trap and improving education quality in Latin America: invest in improving central state capacity as in Europe and Asia, or follow the philanthropy-driven reform model in the United States. While most low- and middle-income countries have solved the problem of educational access, Latin America suffers from what the World Bank (2018) considers a 'learning crisis'. Latin America in particular has high school enrolment rates on par with Europe and East and Central Asia. However, its educational quality is lower-and the core component associated with educational quality is teacher quality, a particular challenge in Latin America (Elacqua, Hincapié, Vegas \& Alfonso, 2018).

\section{THE MIDDLE-INCOME TRAP}

A consequence of Peru's economic boom during the early twenty-first century was its re-classification as an upper middle-income country in 2005 by the World Bank. In an interview with El País in 2012, Bill Gates highlighted Peru as an example of a middle-income country which no longer needed development assistance. You can change many more things in poor countries than when you give aid to a middle-income country like Peru, Gates said. He continued, It has its own mineral resources to exploit and could become as rich as any European country (Aguirre, Gonzalez, Almodova, and de la Rua, 2012).

Middle-income countries include those with GDP per capita of USD 1,026 to USD 12,475, at 2011 prices. According to the World Bank (2017b), 'middle-income countries are home to five of the world's seven billion people and $73 \%$ of the world's poor people'.

Increasing national returns from commodities contributed to employment creation and welfare gains, both of which raised per capita incomes. In Peru, for example, GDP per capita tripled from 2000 to 2016. A challenge is for countries dependent on commodity exports to escape the 'resource curse' by using proceeds from times of bonanza to diversify production, thus decreasing exposure to commodity cycles while generating more employment for the socially mobile population, as the case of Peru shows (Bird, 2016).

The middle-income criterion assumes that per capita income is an adequate measure of development and that middle-income countries are relatively homogenous in social and economic structure. But evidence suggests that this is not the case given differences in poverty, social inclusion, 
production, institutions and financial capacity (Bárcena, Prado, Titelman \& Pérez, 2011, 2012). For countries with low relative per capita income, a rise in this indicator correlates with an increase in national living standards. Yet this relationship dissolves once passing an income threshold, as seen in countries with high levels of inequality and export commodity dependence, which makes them vulnerable to international shocks. Latin America meets these criteria.

Regardless, the middle-income reclassification triggered a progressive shift of ODA out of Latin America. During the 1960s, ODA to Latin America represented one per cent of the regional GDP and accounted for 14 per cent of the total disbursed, according to the OECD (Agencia Peruana de Cooperación Internacional [APCI], 2016). In the 1990s, the ratio of ODA to regional GDP was on average 0.4 per cent and dropped to 0.2 per cent, reflecting the decreasing trend of ODA to the region as many countries were re-classified as middle-income.

The case of Peru mirrors the fall in ODA for middle-income countries in general. World Bank data indicate that despite an overall increase in ODA between 1990 and 2011, the proportion of ODA channelled to the roughly 100 middle-income countries fell from around 55 per cent to 40 per cent of total ODA, with absolute amounts for middle-income countries remaining constant for over two decades (Alonso, Glennie \& Sumner, 2014).

\section{PERU'S SOCIAL INVESTMENT CHALLENGE}

Between 2000 and 2016, Peru's per capita GDP tripled, and in 2008 the country registered the second highest GDP growth in the world, according to the World Bank (Bird, 2016). Consistent GDP growth, led by the mining commodities boom and prudent economic policies, enabled Peru to achieve the second highest international investment grade credit ratings in Latin America, according to the three major international credit rating agencies.

Positive economic performance coincided with a fall in international development aid and a concomitant rise in international private aid. By the end of the 1990s, annual flows of Non-Reimbursable Financial Cooperation (NRFC) reached an average of USD 356 million, 83 per cent of which was from ODA, while the balance of 17 per cent was related to private institutions. Since 2005, when Peru was classified as an upper middle-income country, the proportion of NRFC from ODA to private institutions nearly inverted. NRFC reached a historical high of USD 585 million in 2005 and decreased on average 10 per cent per year between 
2006 and 2010, with the lowest level of NRFC in 20 years (USD 337 million) in 2014 (APCI, 2016).

On the other hand, the national public budget allocated to education doubled from 2009 to 2017 (Romainville, 2017). In 2017, the Peruvian government spent approximately USD 8.0 billion on education, equivalent to 18.4 per cent of the national budget, making the sector the largest recipient of government funds (Castillo, 2017). Yet, as of 2017, Peru ranked last in South America in terms of public spending in education as a percentage of GDP (Busso, Cristia, Hincapié, Messina \& Ripani, 2017).

The evolution of Peruvian macroeconomic data, the increase in public spending and the improvement of quality of life indices would lead one to expect that related human capital measures, such as education, also improved. But this has not been the case, as the World Bank observed: 'From 1990 onward, despite significant investment in basic education and health services that greatly increased coverage, Peru experienced a persistent lack of progress with respect to human development outcomes' (World Bank, 2017a, para. 1). While the economic conditions of the average Peruvian advanced between 2000 and 2015, improvements in education during the same period were not as pronounced. Although per capita income tripled from 2000 to 2016, other parameters captured by the Human Development Index (HDI) ${ }^{1}$ increased only modestly, particularly education. Mean years of schooling rose from 6.6 in 1990 to 8.0 in 2000. Thereafter, the figure began to plateau with 8.4 years in 2005 to 8.8 in 2010 and remained stagnant at 9.0 years from 2012 to 2015.

Programme for International Student Assessment (PISA) results also evidence the gap between economic success and educational achievement. Peru participated in PISA in 2000 and has been evaluated every three years since 2009. PISA evaluates 15-year-old students in the areas of mathematics, reading and science. Results of the 2012 PISA showed that Peru ranked last of the 65 evaluated countries in the three areas measured. The country's ranking and scores slightly improved in the 2015 evaluation, and of the 72 countries evaluated, it placed 64th in mathematics, 66th in reading and 65th in science (OECD, 2016).

Peru reflects a global pattern wherein other middle-income countries, who have progressively lost ODA, face the challenge of closing the educational achievement gap. The substitution between reduced ODA with increased national income does not translate into increased educational achievement because investment in educational quality is mediated by the

1 The Human Development Index, developed by the United Nations Development Program, focuses not on economic indicators to measure poverty but on a long and healthy life, access to knowledge and a decent standard of living. 
state. The government and the private sector have recognised the human development and, more specifically, educational achievement challenge. But to what extent have the philanthropic and social investment interventions in the education sector helped cover this gap?

\section{METHODOLOGY}

In 2016, a network of researchers from Peru and 23 other countries collected data via a standardised survey to create the inaugural Global Philanthropy Report $(G P R)$, an international initiative led by the Hauser Institute for Civil Society at Harvard University's Kennedy School (Johnson, 2018).

Using the GPR as a starting point, the Peruvian survey was revised and administered in the country's 10 largest cities to 157 philanthropic and social investment organisations, which included both operating and grant-making entities (León \& Bird, 2018). Our sample focused only on organisations involved with social investment via philanthropy, as opposed to narrowly defined corporate social responsibility (CSR), which refers to the goal of investing resources to realise non-financial business returns such as enhanced reputation, more engaged employees, increased retention, legal compliance, a social license to operate or content for marketing and branding campaigns (Matten \& Moon, 2008).

The sample was drawn from multiple sources. The first source consisted of a list of registered foundations gathered by the Consejo de Supervigilancia de Fundaciones (Foundations Supervisory Board [CONSUF]), which is part of Peru's Ministry of Justice. The registry provided by the CONSUF included 323 foundations, of which 153 were discovered as active with 90 of these completing the survey. The closed foundations were verified via media searches, site visits and cross-referencing with tax authorities.

The sample also consisted of non-profit associations, a legal form used in Peru as a philanthropic vehicle. We used two sources to identify the philanthropic universe legally constituted as non-profit associations. First, we accessed a database of all the non-profit associations in Peru provided by the Superintendencia Nacional de Registros Públicos (National Records Office [SUNARP]), a government agency. The second source was the Registro de Entidades Perceptoras de Donaciones (Registry of Grant-Receiving Entities) provided by the national tax authority. This list was cross-referenced with the list provided by SUNARP. The strategy to detect non-profit associations that fit our criteria included filtering the list using keywords and employing a snowball sampling strategy. Sixty-seven non-profit associations completed the survey.

The survey was divided into six sections: (i) general information, such 
as year of founding; (ii) governance, including information on governance; (iii) financial information, including assets, income, expenses and grant activity; (iv) organisational focus, including beneficiary sectors and geographic focus; (v) operational strategies, including collaboration with peers and government; and (vi) evaluation and reporting.

Eighty-seven per cent of the surveys were administered in person and 13 per cent were submitted using an online survey form by the research team between the third quarter of 2016 and the first quarter of 2017. All surveys were input into Qualtrics, an online survey system, and exported into STATA where the database was cleaned, standardised and coded. We performed descriptive statistical analysis and, where indicated, multivariate regressions in STATA 13.

Qualitative data were also collected via in-depth semi-structured personal interviews with 32 organisation leaders and leading philanthropists who founded, fund and/or are members of the organisations' governing bodies. Interviews were then transcribed and coded in NVivo for analysis.

\section{PHILANTHROPY IN EDUCATION IN PERU}

\section{Mapping Philanthropy in Education in Peru}

Fifty per cent of the organisations surveyed reported investing in education. Our analysis mapped aspects related to investments, age, revenue models, beneficiaries and geographic scope.

Eighty-seven per cent of the organisations that invested in education shared financial information, and of those that shared information, the average spending in their previous fiscal year was USD 387,535. The spending distribution in the sector was highly skewed, with median investment of USD 49,376. Overall, 10 per cent of organisations spent more than USD 1.0 million, 32 per cent between USD 100,000 and USD 1.0 million, 23 per cent between USD 20,000 and USD 100,000 and 35 per cent less than USD 20,000. Twenty per cent of the organisations provided grants, though none were purely grant-making organisations.

While the Peruvian government's investment in education was approximately USD 8.0 billion in 2017, our survey indicated that the philanthropic sector invested USD 27.5 million in education. This estimate of social investment in education is in line with the amounts reported by the mining sector to the Ministry of Mining. As Peru's largest industry with arguably the largest incentives to invest in local public goods, the total social investment spending in education from the mining sector in 2016 was USD 16 million (Arrieta \& Zavala, 2017). 
Even if we assume that only one-third of the philanthropic investment in the sector was registered, a very conservative estimate, the figure would still represent 0.01 per cent of the 2017 national education budget. This philanthropy to public investment ratio is the same as in the United States (Ferris, Hentschke \& Harmssen, 2008).

We segmented organisations based on their main sources of revenue: corporate, family, foreign-funded local affiliates, self-sustaining and diversified:

- Corporate: financing from one or more companies that represents more than 50 per cent of the organisation's revenues. This group includes philanthropic organisations created by companies and partner entities of companies that only receive donations from them.

- Family: financing from one or more families or individuals that represents more than 50 per cent of the organisation's revenues. This group includes philanthropic organisations created by families or individuals and that obtain the highest percentage of their income from specific, periodic or sporadic contributions from individuals and families.

- Local affiliates: financing from other non-profit organisations that represents more than 50 per cent of the organisation's revenues. This group includes affiliate organisations supported by international organisations.

- Self-sustaining: financing from rents, sponsorships, services or events that generates more than 50 per cent of the organisation's revenues. This group includes organisations that do not have external economic financing but generate their own funds from the use of their assets or sale of goods and services.

- Diversified: financing from various sources with none of these sources representing more than 50 per cent of the organisation's revenues. This group includes recipient organisations (companies, families and organisations) that generate their own income.

Differences in the ages of the organisations are apparent when segmented by revenue model (see Table 8.1). The average age of the organisations investing in education was 22 years, with no significant difference between spending range groups.

Corporate and family organisations comprised the largest percentage of the total, accounting for a combined 60 per cent of the sector, and were also the youngest. The average and median age of the corporate and family sectors were 17 years (median of 13 years) and 18 years (median 
Table 8.1 Philanthropic investment in education-organisation type and age

\begin{tabular}{lcccc}
\hline & Organisations & Sector $(\%)$ & $\begin{array}{c}\text { Average Age } \\
\text { (years) }\end{array}$ & $\begin{array}{c}\text { Median Age } \\
\text { (years) }\end{array}$ \\
\hline Corporate & 26 & 33 & 17 & 13 \\
Family & 21 & 27 & 18 & 8 \\
Local Affiliates & 7 & 9 & 21 & 14 \\
Self-sustaining & 12 & 15 & 30 & 22 \\
Diversified & 13 & 16 & 32 & 26 \\
Full Sample & 79 & 100 & 22 & 14 \\
\hline
\end{tabular}

Table 8.2 Philanthropic investment in education - area

\begin{tabular}{lcccc}
\hline & $\begin{array}{c}\text { Early } \\
\text { Childhood }(\%)\end{array}$ & $\begin{array}{c}\text { Elementary } \\
(\%)\end{array}$ & $\begin{array}{c}\text { Secondary } \\
(\%)\end{array}$ & $\begin{array}{c}\text { Post-secondary } \\
(\%)\end{array}$ \\
\hline Corporate & 42 & 73 & 62 & 28 \\
Family & 57 & 62 & 24 & 24 \\
Local Affiliates & 57 & 43 & 29 & 29 \\
Self-sustaining & 67 & 42 & 25 & 17 \\
Diversified & 46 & 77 & 38 & 38 \\
Full Sample & 48 & 37 & 39 & 30 \\
\hline
\end{tabular}

Note: Organisations could submit multiple answers.

of eight years), respectively, which aligns with the emergence of the global commodity boom and Peru's macroeconomic growth in the early 2000s. The age dispersion within the family category was due to the existence of older family foundations combined with the creation of family organisations in the previous 10 years. The longer existence of the self-sustaining and diversified organisations stemmed from the presence of developmentminded and church organisations.

Forty-eight per cent of education-focused organisations invested in early childhood, as shown in Table 8.2, for areas ranging from early stimulation to nutrition. Elementary and secondary areas attracted the next highest percentage of organisations with 37 per cent and 39 per cent, respectively, while post-secondary education received attention from less than a third of our sample.

Subtle patterns emerge when examining the target areas by revenue model (see Table 8.2). Corporate organisations focused on elementary and secondary education. Qualitative evidence suggests that this emphasis 
may have been due to the corporate organisations' concern with their employees' children.

Regarding the geographic scope of investment, nearly 60 per cent of the organisations invested 80 per cent or more of their resources in their local communities. On the other hand, less than 23 per cent invested 80 per cent or more of their resources at the national level. The remainder distributed investments more evenly between local and national domains. Much of this is explained by revenue model, with 65 per cent of corporate organisations focusing on local communities, while 57 per cent of family organisations concentrated locally. The focus on local communities may have stemmed from corporate and family interests in their local areas of influence.

On the other end, 23 per cent of corporate and 19 per cent of family organisations specified a national focus. On the whole, local affiliate, diversified and self-sustaining organisations lacked a more national focus. Compared to corporate and family organisations, self-sustaining and diversified organisations tended to balance their investments between national and local domains.

As for how organisations invest, they mainly do so through their own programmes and scholarships, followed by in-kind donations. The least used mechanism is grant-making, defined as a transfer of grant funds to other organisations (see Table 8.3).

In summary, surveyed organisations were young, locally focused and small. Given the slight size of philanthropic investment relative to the public education budget, the ability to leverage investments and generate impact at scale becomes even more critical.

Table 8.3 Philanthropic investment in education-by mechanism

\begin{tabular}{lcccc}
\hline & $\begin{array}{c}\text { Programmes } \\
(\%)\end{array}$ & $\begin{array}{c}\text { Grants / Monetary } \\
\text { Giving }(\%)\end{array}$ & $\begin{array}{c}\text { Scholarships } \\
(\%)\end{array}$ & $\begin{array}{c}\text { In-kind } \\
\text { Donations }(\%)\end{array}$ \\
\hline Never & 3 & 61 & 39 & 37 \\
Almost never & 1 & 14 & 5 & 18 \\
Sometimes & 9 & 14 & 20 & 27 \\
Most of the & 14 & 4 & 18 & 9 \\
$\quad$ time & 73 & 8 & 18 & 10 \\
Always & & & & \\
\hline
\end{tabular}

Note: Organisations could submit multiple answers. 


\section{Institutional Quality: Transparency, Governance and Operational Mechanisms}

The ability to effectively leverage philanthropic investment is influenced by aspects related to institutional quality as measured by transparency, governance and operational mechanisms.

\section{Transparency}

We gathered data related to the philanthropic organisations' presence on the internet and in social media, compiled information, and used it to gauge transparency. We assert that organisations that answered affirmatively to the survey questions reflected a higher commitment to transparency by gathering and sharing data related to their financial and organisational performance. Presence on the internet included a proprietary website, Facebook or Twitter. Eighty-one per cent of the organisations had a proprietary website, 66 per cent had presence on Facebook and 35 per cent used Twitter.

When organisations responded that they compiled information, we asked them to classify it into financial and organisational information. Financial information gathered had an additional degree of detail, including a summary of expenses, and unaudited versus audited financial statements. Similarly, organisational information included data on beneficiaries and activity reports.

Eighty-two per cent of our sample gathered information, and all that compiled information reported that they prepared a report of activities. Additionally, 59 per cent generated a summary of expenses, 14 per cent prepared a report of their beneficiaries, 47 per cent generated audited financial statements and 46 per cent prepared unaudited financial statements. Forty-one per cent of the organisations that generated information made publicly available a report of activities, eight per cent published a summary of expenses, five per cent published a report of their beneficiaries and 11 per cent published audited financial statements.

So, while 82 per cent of the organisations surveyed gathered information, only 41 per cent published it. All of the published information included a 'report of activities', while 5 per cent was related to beneficiaries and 11 per cent was audited financial statements. These results indicated limited sharing of information related to financial and organisational performance.

\section{Governance}

To analyse governance structure, we surveyed aspects related to the organisations' governing bodies. Ninety-seven per cent of the organisations 
reported that they had a governing body. We further inquired about the profile of the governing body and its members. The average governing body consisted of seven members, and 51 per cent of the board members were external, 53 per cent did not have a specified length for service and 79 per cent received no compensation. Members of the governing body served a median of three years, attended 6.2 meetings per year and were 39 per cent female.

Our data suggested that larger governing bodies were more likely to publish audited financial information, and two-thirds of the organisations that published audited financial statements were corporate. Of note, the length of service in a governing body related to the likelihood to publish financial information - the median length of service of the governing body members in organisations that published was 2.6 years, while that for those that did not publish was 5.1 years, which may suggest that newer governing body members made greater demands on financial transparency.

\section{Operational mechanisms}

Finally, we surveyed organisations on issues related to their operational mechanisms. An analysis of these mechanisms allowed us to identify their level of strategic execution. To determine an organisation's operational mechanisms, we analysed collaboration with peers and government and the development and use of evaluations.

Collaboration is a fundamental component of an organisation's operations. Therefore, we surveyed organisations on their experience collaborating with peers and government. In both cases, we asked whether they engaged in peer learning, co-development and planning of projects or cofunding of initiatives. Organisations could list all the methods they used to collaborate with peers and government and answers included roundtables, research development, cooperation agreements, and supply of services and goods. Sixty-eight per cent of the organisations reported that they collaborate with peers, while 65 per cent reported that they collaborate with government. Of those that collaborate with peers, 53 per cent did so via the co-development of programmes, 49 per cent through peer learning and 29 per cent with joint financing. Of those that collaborated with government, 51 per cent collaborated in the development of programmes, 34 per cent with peer learning and 24 per cent with joint financing. When asked why they did not collaborate more with government, the reasons cited included negative past experiences, incompatibility with public structures, bureaucratic constraints, and political instability which affects continuity. As a sector, however, nearly twice as many education organisations (31 per cent) compared to non-education organisations (16 per cent) collaborated with the government. 
We also asked organisations whether they conducted evaluations. If so, we requested an explanation of the type of evaluations conducted, and if results were disseminated internally, externally or both. Seventy-eight per cent responded that they conducted some type of evaluation. Of the organisations that conducted evaluations, over two-thirds reported that they engaged in one or a combination of needs evaluations, process evaluations, qualitative results evaluations, results evaluations without a control group and impact evaluations with a control group and that results were used only for internal purposes. Nineteen per cent of these evaluations were performed by external parties. Twenty-five per cent of the organisations that conducted evaluations used impact evaluations with a control group, the most rigorous type of evaluation. Of the organisations that conducted this type of evaluation, 17 per cent engaged an external party to perform it.

Related to the dissemination of evaluations, we also asked organisations to explain their use. Ninety-seven per cent responded that they used them for internal purposes, 38 per cent for marketing purposes, 29 per cent to influence public policy and 43 per cent for fundraising.

We found, using regression analysis, that there was no statistically significant relationship between publishing audited financial information and conducting evaluations regardless of type. Similarly, there was no statistically significant relationship between the profile of the governing body and an organisation performing evaluations. Over half of the organisations that published financial information and evaluations with external parties were corporate, even though only a third of the education-focused philanthropic organisations came from the corporate sector. Of note, organisations that published audited financial information were twice as likely to use their evaluation evidence publicly for marketing, policymaking and fundraising.

Two-thirds of the organisations that published audited financial information also engaged a third party to conduct impact evaluations with a control group, while only 10 per cent of those that did not publish audited financial information engaged a third party to conduct impact evaluations with a control group.

In sum, an analysis of information transparency, governance and operational mechanisms sheds light on the institutional quality of philanthropic investment in education in Peru. We discovered a link between governing bodies with members with a shorter length of service and the organisation's likelihood to compile and share information. We also found that those most likely to publish audited financial statements conducted the most rigorous impact evaluations with control groups which were performed by third parties. 


\section{CONCLUSION}

In 2005, Cynthia Sanborn observed that 'a good part of [Latin America's philanthropy] remains scattered and relatively ineffective to produce significant social change - and much of it does not even try' (Sanborn, 2005, p. 46). Our survey in 2017 shows that more are trying.

What can we learn from the Peruvian organisations we surveyed and interviewed that could be applicable to other middle-income countries? While the organisations we analysed have a will to influence the sector, do they contribute with ways to translate the country's economic success to educational achievements?

The ratio of philanthropic investment in education to the national education budget in Peru is similar to the ratio in the United States. Therefore, as in the United States, the efficient and strategic deployment of the investment is more relevant than the amount of the investment per se. Despite the significant increase in public investment in the Peruvian national budget, Peru still lags the region in percentage of GDP investment in the sector and educational achievement. Can Peruvian philanthropy close the gap?

The challenge Peru and other middle-income countries face is how to leverage philanthropic investments to generate systemic change. Philanthropic organisations involved in education in Peru are small, young and locally focused. Three-quarters of the organisations conduct evaluations and more than half collaborate with peers and government. However, only a small percentage share results of their evaluations, and an even smaller percentage share audited financial information.

Model organisations share characteristics related to transparency, governance and operational mechanisms (Frumkin, 2005). Media presence, dissemination of financial and operational information, an active governing body with a clear mission, collaboration with peers and government, and the performance and sharing of evaluations are all components that reflect institutional quality. These institutional quality indicators are critical for being successful within a philanthropy-driven reform model.

But how can a small, young, locally focused organisation evolve to a regional benchmark with strong institutional quality, thereby influencing education in Peru? How can these organisations contribute in the process of translating middle-income countries' economic success into well-educated citizens? The analysis of the aforementioned components of institutional quality may provide a prescription for pathways to scale with impact. 


\section{ACKNOWLEDGEMENTS}

Special thanks to Alejandra Hidalgo, Frida Infante, Erika León and Jorge Zavala for their research assistance and Milagros Otaegui for administrative support. All errors or omissions are our own.

\section{REFERENCES}

Agencia Peruana de Cooperación Internacional (APCI). (2016). Situación y tendencias de la cooperación internacional en Perú 2011-2014 [Situation and trends of international cooperation in Peru 2011-2014]. Lima, Peru: Author. Retrieved in 2017 from http://www.apci.gob.pe/gestion/atach/Situacion_y_Tendencias/ Situacion_y_Tendencia_2011_2014.pdf

Aguirre, L., Gonzalez, B. Almodova, L., \& de la Rua, A. (2012, February 22). Entrevista con Bill Gates: 'La ayuda debe ir a los más pobres, no a países con ingresos medios como Perú' [Interview with Bill Gates: 'Help should go to the poorest, not to countries with middle incomes such as Peru']. El País. Retrieved in 2017 from https://elpais.com/sociedad/2012/02/22/actualidad/1329913536_647673.html

Alonso, J. A., Glennie, J., \& Sumner, A. (2014). Recipients and contributors: Middle income countries and the future of development cooperation (DESA Working Paper No. 135, ST/ESA/2014/DWP/135). Geneva, Switzerland: United Nations.

Arrieta, J., \& Zavala, J. (2017). El efecto de la inversion pública y privada en desarrollo sobre la generación y resolución de conflictos sociales en el sector minero [The effect of public and private investment on the creation and solution of social conflicts in the mining sector]. Unpublished undergraduate thesis, Universidad del Pacífico, Lima, Peru.

Bárcena, A., Prado, A., Titelman, D., \& Pérez, R. (2011). El financiamiento para el desarrollo y los paises de renta media: nuevos desafios [The financing of development and middle-income countries: new challenges]. Santiago, Chile: CEPA. Retrieved in 2017 from https://repositorio.cepal.org/bitstream/handle/11362/2999/1/S20110 42_es.pdf

Bárcena, A., Prado, A., Titelman, D., \& Pérez, R. (2012). Los países de renta media: Un nuevo enfoque basado en brechas estructurales [Middle income countries: a new focus based on structural gaps]. Santiago, Chile: CEPAL. Retrieved in 2017 from https://repositorio.cepal.org/bitstream/handle/11362/13787/1/S2012863_es.pdf

Bird, M. (2016). Economic aspects of entrepreneurship: The case of Peru. In C. Williams \& A. Gurtoo (Eds.), Handbook of entrepreneurship in developing economies (pp. 113-130). London, UK: Routledge Press.

Busso, M., Cristia, J., Hincapié, D., Messina, J., \& Ripani, L. (Eds.). (2017). Aprender Mejor: Políticas públicas para el desarrollo de habilidades [Better learning: public policies for the development of skills]. Washington, DC: InterAmerican Development Bank.

Castillo, N. (2017, August 31). Educación: Alertan que presupuesto para 2018 reduce peso del sector y MEF responde [Education: alert that the 2018 budget decreases the weight for the sector and the MEF responds]. El Comercio. Retrieved in 2017 from https://elcomercio.pe/economia/peru/educacion-alertanpresupuesto-2018-reduce-peso-sector-mef-responde-noticia-454513 
Elacqua, G., Hincapié, D., Vegas, E., \& Alfonso, M. (2018). Profesión: profesor en América Latina ¿Por qué se perdió el prestigio docente y cómo recuperarlo? [Profession: professor in Latin America. Why did the profession lose its prestige and how to recuperate it]. Washington, DC: Banco Interamericano de Desarrollo.

Ferris, J., Hentschke, G., \& Harmssen, H. (2008). Philanthropic strategies for school reform: An analysis of foundation choices. Educational Policy, 22, 705-730.

Frumkin, P. (2005). On being nonprofit: A conceptual and policy primer. Cambridge, MA: Harvard University Press.

Hauser Center. (2016). From prosperity to purpose: Perspectives on philanthropy and social investment among wealthy individuals in Latin America. Cambridge, MA: Harvard Kennedy School of Government.

Johnson, P. (2018). Global philanthropy: Data and perspectives on philanthropic institutions around the world. Cambridge, MA: Harvard Kennedy School of Government.

León, V., \& Bird, M. (2018). Hacia una nueva filantropía en el Perú [Towards a new philanthropy in Peru]. Lima, Peru: Editorial de la Universidad del Pacífico.

Matten, D., \& Moon, J. (2008). 'Implicit' and 'explicit' CSR: A conceptual framework for a comparative understanding of corporate social responsibility. Academy of Management Review, 33(2), 404-424.

Organisation of Economic Co-operation and Development. (2016). PISA 2015: PISA results in focus. Paris, France: Author.

Portocarrero, F., Sanborn, C., Cueva, C., \& Millán, A. (2002). Más allá del individualismo: El tercer sector en el Perú [Beyond individualism: the third sector in Peru]. Lima, Perú: Universidad del Pacífico.

Romainville, M. (2017, August 19). Educación: La evolución del presupuesto en los últimos ocho años [Education: the budget's evolution during the last eight years]. El Comercio. Retrieved in 2017 from https://elcomercio.pe/economia/ peru/educacion-evolucion-presupuesto-ultimos-nueve-anos-noticia-451352

Sanborn, C. (2005). Philanthropy in Latin America: History and current trends. In C. Sanborn \& F. Portocarrero (Eds.), Philanthropy and social change in Latin America (pp. 3-30). Cambridge, MA: David Rockefeller Center for Latin American Studies, Harvard University.

Sanborn, C., \& Portocarrero, F. (Eds.). (2005). Philanthropy and social change in Latin America. Cambridge, MA: David Rockefeller Center for Latin American Studies, Harvard University.

Soskis, B., \& Katz, S. (2016). Looking back at 50 years of U.S. philanthropy. Menlo Park, CA: The William and Flora Hewlett Foundation.

Stiglitz, J. (1996). Some lessons from the East Asian miracle. World Bank Research Observer, 11(2), 151-177.

Tompkins-Stange, M. (2016). Policy patrons: Philanthropy, education reform, and the politics of influence. Cambridge, MA: Harvard Education Press.

World Bank. (2017a). Strengthening results and accountability frameworks in education, health, and nutrition in Peru. Retrieved in 2017 from http://www. worldbank.org/en/results/2017/04/05/strengthening-results-accountability-frame works-education-health-nutrition-peru

World Bank. (2017b). The World Bank in middle income countries. Retrieved in 2017 from http://www.worldbank.org/en/country/mic/overview

World Bank. (2018). World Development Report, 2018: Learning to realize education's promise. Washington, DC: Author. 